\title{
ARTYKUtY
}

Klio. Czasopismo poświęcone dziejom Polski i powszechnym

PL ISSN 1643-8191, t. 50 (3)/2019, s. 83-104

(c) (1) $\Theta$

http://dx.doi.org/10.12775/KLIO.2019.027

Michat Piekarski"

\section{Zajęcia z zakresu muzykologii na Uniwersytecie Stefana Batorego. Przyczynek do dziejów uczelni}

\section{Musicology Classes at the Stefan Batory University. An aspect of the History of the University}

Streszczenie. Muzykologia na uniwersytetach w Krakowie i Lwowie pojawiła się w przededniu pierwszej wojny światowej, niedługo po jej wprowadzeniu na uczelniach niemieckojęzycznych. Plany wprowadzenia zajęć z zakresu muzykologii na Uniwersytecie Stefana Batorego wiązały się z obecnością w Wilnie ks. Hieronima Feichta, absolwenta lwowskiej muzykologii, który przybył do Wilna w 1926 roku jako kierownik Małego Seminarium Księży Misjonarzy. Jednocześnie nawiązał kontakt z USB. Choć zamierzenie to nie doszło do skutku, to zajęcia z muzykologii objął w 1933 roku Tadeusz Szeligowski.

* Instytut Historii Nauki PAN, ul. Nowy Świat 72, 00-330 Warszawa, michal.piekarski@interia.pl, ORCID: 0000-0001-5045-6100. 
Abstract. Musicology made its appearance on Polish universities before World War One in Krakow and Lwow, shortly after it was formally established at German-speaking universities. An idea to establish musicology in Stefan Batory University in Wilno was strictly connected with father Hieronim Feicht, who graduated from Faculty of Musicology of Lwow University. He came to Wilno in 1926 as a head of Missionaires Seminary. In the same time he made a contact with USB. Despite the plans connected with father Feicht never carried out, from 1933 the course of musicology was conducted by Tadeusz Szeligowski.

Słowa kluczowe: Wilno, uniwersytet, muzykologia, muzyka

Keywords: Vilnius, university, musicology, music

$\mathrm{M}$

uzykologia na polskojęzycznych uniwersytetach pojawiła się w przededniu pierwszej wojny światowej, niedługo po jej wprowadzeniu na uczelniach niemieckojęzycznych ${ }^{1}$. Wykłady z zakresu tej dyscypliny w mury Uniwersytetu Jagiellońskiego wprowadził w 1911 roku Zdzisław Jachimecki, a Uniwersytetu Lwowskiego - w 1912 roku Adolf Chybiński. Wiązało się to z uzyskaniem przez obydwu habilitacji, po czym zostali zatrudnieni jako docenci prywatni. Na uczelniach tych początkowo nie funkcjonowały katedry muzykologii, a jedynie prowadzone były zlecone zajęcia (katedrę mógł otrzymać wyłącznie profesor). Pierwsza Katedra Historii i Teorii Muzyki oficjalnie powstała w 1917 roku, wraz z otrzymaniem profesury przez Adolfa Chybińskiego, a nadało ją Ministerstwo Wyznań i Oświaty w Wiedniu². Tytuł profesora zwyczajnego otrzymał w 1921 roku za sprawą mianowania przez Naczelnika Państwa Józefa Piłsudskiego ${ }^{3}$. Zdzisław Jachimecki profesurę nadzwyczajną otrzymał w 1918 roku w Krakowie (zwyczajną również tam w 1921 roku).

1 Pierwszy Instytut Muzykologii powstał w 1898 r. na Uniwersytecie Wiedeńskim. Wykłady z zakresu tej dyscypliny pojawiły się tam już w $1856 \mathrm{r}$.

2 Państwowe Archiwum Obwodu Lwowskiego, dalej: [DALO], фонд [f.] 26, опись. [op.] 5, справа [spr.] 2014, Ministerium für Kultus und Unterricht an das Dekanat der philosophien Fakultät der k.k. Universität in Lemberg, Wien, 1 I 1917, mps, k. 135.

3 DALO, f. 26, op. 5, spr. 2014 [Pismo Ministerstwa WRiOP do A. Chybińskiego] [Warszawa] 28 VI 1921, mps, k. 203. 
Obydwaj do 1939 roku obejmowali katedry, które za ich sprawą pojawiły się na Wydziałach Filozoficznych (we Lwowie od 1924 roku był to Wydział Humanistyczny) $)^{4}$.

Trzecim z kolei ośrodkiem polskim był Uniwersytet Poznański ${ }^{5}$, gdzie zajęcia o tej tematyce pojawiły się w 1919 roku, już w pierwszym roku istnienia tej uczelni, prowadzone przez ks. Wacława Gieburowskiego ${ }^{6}$ jako seminarium muzykologiczne ${ }^{7}$. Z kolei w roku akademickim 1921/1922 na Uniwersytecie Poznańskim wykłady z muzykologii rozpoczął Łucjan Kamieński, najpierw jako zastępca profesora, mianowany $\mathrm{w}$ tym samym roku profesorem nadzwyczajnym muzykologii (bez habilitacji) ${ }^{8}$. Od roku akademickiego 1929/1930 funkcjonował Zakład Muzykologiczny, do 1939 roku kierowany przez Kamieńskiego'. Na Uniwersytecie Poznańskim za sprawą ks. Gieburowskiego powstało też stanowisko docenta teorii i historii muzyki kościelnej, które przysługiwało mu od roku akademickiego $1924 / 1925^{10}$.

4 Szerzej na ten temat zob. M. Piekarski, Przerwany kontrapunkt. Adolf Chybinski i początki polskiej muzykologii we Lwowie 1912-1944, Warszawa 2017.

5 Dla porównania seminarium muzykologiczne na Uniwersytecie Berlińskim powstato w $1904 \mathrm{r}$.

6 Ks. Wacław Gieburowski (1877-1943), studiował m.in. w Kirchenmusikschule w Ratyzbonie, w latach 1909-1913 odbywał zaocznie studia muzykologiczne w Berlinie i we Wrocławiu (doktorat - 1915). Wykładowca w Seminarium Duchownym w Poznaniu oraz w Państwowym Konserwatorium Muzycznym. W 1922 r. habilitował się na Wydziale Teologicznym UJK, od 1925 r. docent Uniwersytetu Poznańskiego (wykłady z historii chorału). Kierownik Poznańskiego Chóru Katedralnego (1914-1939). K. Morawska, Gieburowski Wactaw, [w:] Encyklopedia Muzyczna PWM, red. E. Dziębowska, t. 3, Kraków 1987, s. 299-300.

7 Uniwersytet Poznański. Sktad uniwersytetu w roku akademickim 1919/1920, Poznań 1919, s. 11.

8 K. Michałowski, Z historii muzykologii poznańskiej, [w:] Muzykologia na Uniwersytecie im. Adama Mickiewicza w Poznaniu w latach 1974-1999, red. M. Jabłoński, Poznań 1999, s. 50; Uniwersytet Poznański. Sktad uniwersytetu w roku akademickim 1921/1922, Poznań 1921, s. 15.

9 Uniwersytet Poznański. Sktad uniwersytetu w roku akademickim 1929/1930, Poznań 1929, s. 39.

10 Uniwersytet Poznański. Sktad uniwersytetu w roku akademickim 1924/1925, Poznań 1924 , s. 15. 
W Warszawie dopiero w latach trzydziestych czyniono próby powołania uniwersyteckiej muzykologii. Wiązało się to $\mathrm{z}$ utworzeniem w 1934 roku Wydziału Muzykologicznego Państwowego Konserwatorium Muzycznego, który miał funkcjonować we współpracy z Uniwersytetem Warszawskim (inaczej niż w Krakowie, Lwowie i Poznaniu, gdzie muzykologia była niezależna od konserwatoriów muzycznych). Po raz pierwszy w roku akademickim 1935/1936 w spisie wykładowców UW pojawia się Julian Pulikowski jako docent muzykologii (habilitował się w 1936 roku) ${ }^{11}$. Jednak dopiero w następnym roku muzykologia trafia do spisu zajęć UW, gdzie widnieje do $1939 \mathrm{roku}^{12}$. Próba powołania muzykologii na UW, natrafiając na rozmaite przeszkody, nie przyniosła jednak rezultatów na miarę innych polskich ośrodków, przez co do wybuchu drugiej wojny światowej nie było w stolicy placówki muzykologicznej porównywalnej z tymi we Lwowie, Krakowie czy Poznaniu.

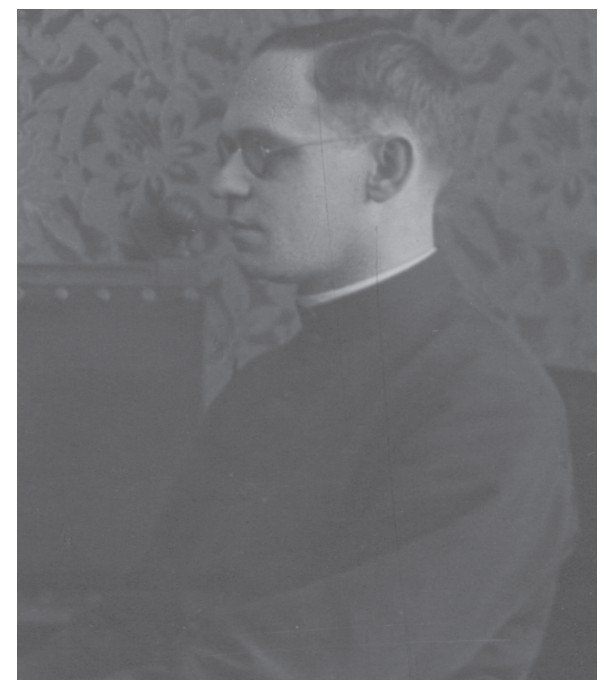

Ryc. 1. Ks. Hieronim Feicht, Lwów 1925 r. Biblioteka Uniwersytecka w Poznaniu,

Oddział Zbiorów Specjalnych, Archiwum A. Chybińskiego, sygn. Rkp. 802

11 Uniwersytet Józefa Pitsudskiego $w$ Warszawie. Sktad uniwersytetu i spis wyktadów na rok akademicki 1935-1936, Warszawa 1935, s. 25.

12 Uniwersytet Warszawski. Sktad uniwersytetu i spis wyktadowców 1936/1937, Warszawa 1936, s. 54. 
W okresie międzywojennym głównym ośrodkiem polskiej muzykologii stał się Zakład Muzykologii Uniwersytetu Jana Kazimierza we Lwowie, prowadzony przez Adolfa Chybińskiego (w Krakowie Zdzisław Jachimecki wciąż borykał się z problemami lokalowymi, stojącymi na przeszkodzie w zorganizowaniu zakładu ${ }^{13}$ ). Absolwenci muzykologii UJK działali także poza Lwowem. Dotyczy to zwłaszcza ks.Hieronima Feichta (ur. w 1894 roku w Mogilnie, zm. w 1967 roku w Warszawie) ze zgromadzenia księży misjonarzy. Po studiach w Instytucie Teologicznym Księży Misjonarzy w Krakowie (dyplom z 1921 roku) ${ }^{14}$ w 1920 roku został mianowany prefektem Arcybiskupiego Małego Seminarium we Lwowie ${ }^{15}$. We Lwowie ks. Feicht w klasie organów Konserwatorium Polskiego Towarzystwa Muzycznego ${ }^{16}$ kontynuował edukację muzyczną zapoczątkowaną w Krakowie u Bolesława Wallek-Walewskiego ${ }^{17}$. Jednocześnie w 1921 roku podjął na UJK studia z muzykologii, które ukończył w 1925 roku praca doktorską Kompozycje religijne Barttomieja Pękiela ${ }^{18}$. W latach 1924-1926 pełnił obowiązki asystenta w Zakładzie Muzykologii UJK (oficjalnie w latach 1925-1926) ${ }^{19}$. Jednocześnie prowadził ćwiczenia z chorału gregoriańskiego na Wydziale Teologicznym UJK od roku akademickiego 1924/1925, a ponadto w roku akademickim 1925/1926 po Chybińskim przejął wykłady z historii muzyki sakralnej ${ }^{20}$.

13 Z. Jachimecki, Muzykologia i piśmiennictwo muzyczne w Polsce, Kraków 1948, s. 36.

14 Archiwum Polskiej Prowincji Zgromadzenia Księży Misjonarzy w Krakowie [APPZKM], Archiwum ks. H. Feichta, sygn. PM0664, Feicht H. II/3/6, Testimonium emensi Studii Theologici, Kraków, 5 IV 1921, rkps, k. 16.

15 APPZKM, Archiwum ks. H. Feichta, sygn. PM0663, Feicht H. II/1, Kwestionariusz [rkps] [k. nlb.].

16 Przed 1918 r. nosiło nazwę: Galicyjskie Towarzystwo Muzyczne.

17 W. Kałamarz, Muzyka u misjonarzy, Kraków 2009, s. 129 i 254.

18 APPZKM, Archiwum ks. H. Feichta, sygn. PM0664, Feicht H. II/3/6 [Pismo Dziekanatu Wydziału Filozoficznego [sic!] UJK do ks. H. Feichta], Lwów, 4 XII 1924, mps, k. 27.

19 APPZKM, Archiwum ks. H. Feichta, sygn. PM0663, Feicht H. II/1, Kwestionariusz, rkps, k. nlb.

20 DALO, f. 26, op. 5 spr. 2015 [Pismo dziekana ks. Piotra Stacha do A. Chybińskiego], Lwów, 12 V 1925, mps, k. 43; Kronika Uniwersytetu Jana Kazimierza we Lwowie za rok szkolny 1924/25 stanowiąca sprawozdanie rektora i dziekanów, oprac. W. Sieradzki, 


\section{Ksiądz Hieronim Feicht trafia ze Luowa do Wilna}

Uniwersytet Stefana Batorego został powołany w 1919 roku, podobnie jak Uniwersytet Poznański. Pierwsze plany wprowadzenia zajęć z zakresu muzykologii wiązały się z obecnością w Wilnie ks. Feichta. Latem 1926 roku musiał on zakończyć pracę we Lwowie, w sierpniu tego roku został bowiem przymusowo skierowany przez władze zakonu do Wilna na stanowisko kierownika Małego Seminarium Księży Misjonarzy (ulica Subocz $18)^{21}$. W Wilnie ks. Feicht pozostawał przez rok: od sierpnia 1926 do lipca 1927 roku. Mimo że próbował wszelkich możliwych sposobów, aby pozostać we Lwowie i kontynuować pracę muzykologa, nawet narażając się władzom zakonu ${ }^{22}$, wszystkie te kroki okazały się bezskuteczne. Niezależnie jednak od przeniesienia na nowe miejsce i konieczności sprostania nowym obowiązkom ks. Feicht nie chciał tracić kontaktu z pracą na uczelni.

Ksiądz Hieronim Feicht już na początku pobytu w Wilnie nawiązał kontakt $\mathrm{z}$ uniwersytetem, gdzie zaoferowano mu prowadzenie wykładów ${ }^{23}$. $\mathrm{Na}$ podstawie listów ks. Feichta do Chybińskiego możemy stwierdzić, że pierwsza propozycja dotyczyła Wydziału Humanistycznego (o czym ks. Feicht donosił Chybińskiemu w listopadzie 1926 roku). Druga możliwość wiązała się z objęciem zajęć na Wydziale Teologicznym (o czym pisał w czerwcu 1927 roku). Warto przypomnieć, że na UJK ks. Feicht już wcześniej prowadził zajęcia na obydwu wydziałach, miał więc gotowe wzorce zajęć. Z kolei Uniwersytet Poznański od kilku lat zatrudniał

Lwów 1924, s. 101; DALO, f. 26, op. 5, sp. 2015 [Pismo dziekana ks. Piotra Stacha do A. Chybińskiego], Lwów 12 V 1925, mps, k. 43.

21 Biblioteka Jagiellońska Oddział Zbiorów Specjalnych [BJ OZS], Korespondencja A. Chybińskiego, teka: F-3/1, list bez sygn., List ks. H. Feichta do A. Chybińskiego [„W pociągu między Krakowem i Zakopanem”] 11 VIII 1926, rkps, k. nlb.

22 Ks. Feicht oświadczył nawet wizytatorowi prowincji oo. misjonarzy, „że przez decyzję swą sam się narazi na przykrości we Lwowie”. BJ OZS, Korespondencja A. Chybińskiego, teka: F-3/1, list bez sygn. List ks. H. Feichta do A. Chybińskiego, Olcza, 12 VIII 1926, rkps, k. nlb.

$23 \mathrm{~W}$ celu pełnego zbadania zagadnienia dotyczącego zajęć z zakresu muzykologii na USB należałoby w dalszej kolejności zapoznać się z dokumentami znajdującymi się $\mathrm{w}$ Wilnie w Lietuvos centrinis valstybes archyvas. 
ks. Gieburowskiego, którego stałym lokum było Seminarium Duchowne (co odnotowywano w składzie osobowym uczelni) ${ }^{24}$. Ponadto, od roku akademickiego 1924/1925 Gieburowski nosił tytuł doktora filozofii, docenta teorii i historii muzyki kościelnej Uniwersytetu Poznańskiego ${ }^{25}$. USB miał więc gotowy przykład zatrudnienia osoby duchownej na stanowisku wykładowcy muzykologii ze specjalnością dotyczącą muzyki kościelnej.

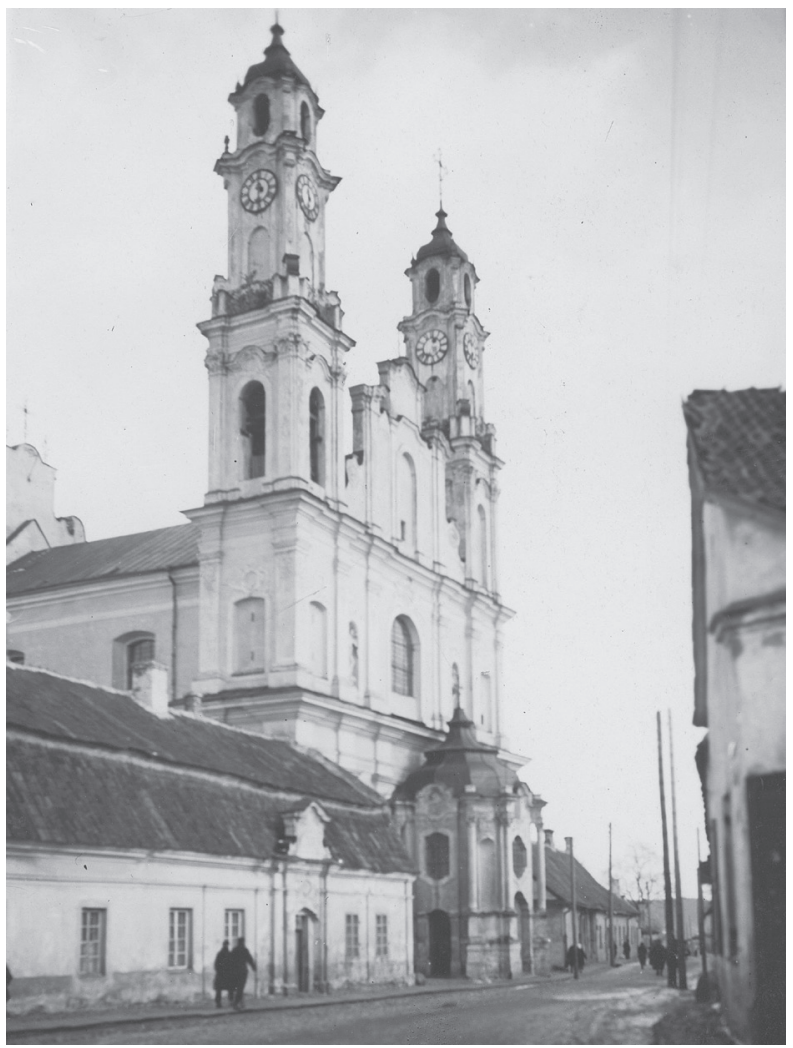

Ryc. 2. Wilno, kościół oo. Misjonarzy przy ul. Subocz. Narodowe Archiwum Cyfrowe, sygn. 1-U-7708

24 Uniwersytet Poznański. Sktad uniwersytetu w roku akademickim 1919/1920, Poznań 1919, s. 11; Uniwersytet Poznański. Sktad uniwersytetu w roku akademickim 1920/1921, Poznań 1920, s. 9.

25 Uniwersytet Poznański. Sktad uniwersytetu w roku akademickim 1924/1925, Poznań 1924 , s. 15. 
Plany zatrudnienia ks. Feichta na USB nie doczekały się jednak realizacji. W związku z propozycją Wydziału Humanistycznego ks. Feicht natrafił na sprzeciw władz zakonu misjonarzy, powodujący, że musiał z niej zrezygnować, o czym zawiadamiał Adolfa Chybińskiego:

\begin{abstract}
Mnie oferował wydział humanist.[yczny] Uniw. [ersytetu] Stef.[ana] Bat. [orego] zlecone wykłady, ale sprawa została oczywiście przez kompetentne czynniki załatwiona w myśl założenia, że członkowie Zgromadzenia nie powinni obejmować posad na uniwersytetach ${ }^{26}$.
\end{abstract}

Powyższy cytat zasługuje na uwagę, po pierwsze dlatego, że jest to pierwsza znana dotąd wzmianka świadcząca o zainteresowaniu władz USB muzykologią. Po drugie, wskazuje na fakt, że władze misjonarskie wyraźnie chciały odseparować ks. Feichta od pracy na uniwersytecie, nakazując wyprowadzkę ze Lwowa. Oczywiście przeniesienie ks. Feichta do Wilna wiązało się też z bieżącymi potrzebami zgromadzenia, jednak wymowny jest fakt uniemożliwienia podjęcia jakichkolwiek zajęć na uniwersytecie. Mimo tego ks. Feicht miał zlecone wykłady powszechne, do których nie przywiązywał jednak większej wagi. Był już jednak zobowiązany je odbyć, nad czym ubolewał: „choć z tego niema [sic] pożytku, a tylko strata czasu na przygotowanie, zwłaszcza że trzeba będzie porządnie wystąpić” ${ }^{27}$.

Mimo nieprzychylnych czynników ks. Feicht, nie zaniechawszy pracy naukowej, rozpoczął samodzielną pracę muzykologiczną (m.in. nad twórczością Marcina Leopolity), sprowadzając do Wilna książki i nuty. Warto zwrócić uwagę, że wśród sprowadzanych nut była też muzyka współczesna takich kompozytorów jak m.in. Leoš Janaček i Zoltán Kodály ${ }^{28}$.

Wobec niedopuszczenia do wykładów na USB ks. Feicht wyrażał Chybińskiemu swoje rozgoryczenie, w nienajlepszym świetle stawiając zakon misjonarzy, pisząc, że należy „»łokciami« zdobywać uznanie w Zgromadzeniu”. Dodawał: „metodę dalej będzie trzeba stosować bez względu zresztą na to, czy będę kiedykolwiek zajmował stanowisko na uniwersytecie

26 BJ OZS, Korespondencja A. Chybińskiego, teka: F-3/1, list bez sygn., List ks. H. Feichta do A. Chybińskiego, Wilno 30 XI 1926, rkps, k. nlb.

27 Ibidem.

28 Ibidem. 
czy nie"29. Jednocześnie, wskutek przemęczenia związanego z obciążeniem obowiązkami zawodowymi, donosił Chybińskiemu, że w „dosyć ostrej formie" przedstawił niestosowność decyzji władz zakonu misjonarzy powierzania mu dyrekcji seminarium w Wilnie ${ }^{30}$. Wobec zaostrzonej sytuacji w zgromadzeniu ks. Feicht nie był w stanie przewidzieć, czy w ogóle powróci do pracy na uczelni. Dlatego też w listach z Wilna - choć pisane były tuż po wyjeździe ze Lwowa - nigdy nie wspominał o rychłej możliwości powrotu na dawne stanowisko asystenta w Zakładzie Muzykologii UJK. Zastanawiał się jednak nad zaistnieniem możliwości powołania w Polsce nowej katedry muzykologii, tym razem powiązanej z teologią. Aby umożliwić sobie dalszą pracę naukową i udział w rozwoju muzykologii w Polsce, za najważniejsze uznał urobienie opinii ,autorytetu w sprawach muzyki kościelnej w sferach duchowieństwa, by w danym wypadku tworzenia jakiejś katedry muzykologii na wydz.[iale] teol.[ogicznym] być najpoważniejszym kandydatem, przy którym ewentualni kontrkandydaci nie bardzo śmieliby się wysuwać"31. Choć do 1939 roku nie powstała w Polsce nowa katedra muzykologii, to myśl ks. Feichta z 1926 roku zasługuje na uwagę wobec powołanej przez niego 30 lat później, w 1956 roku, Katedry Muzykologii na Wydziale Teologicznym Katolickiego Uniwersytetu Lubelskiego ${ }^{32}$.

Ksiądz Feicht, chcąc zyskać autorytet w kręgach kościelnych, publikował sprawozdania z muzyki kościelnej - zwłaszcza w tarnowskiej „Hosannie”, będącej czasopismem poczytniejszym w kręgach duchowieństwa. Jednocześnie ubolewał, że tego rodzaju publikacje bardziej przyczynią się do podniesienia jego prestiżu niż poważne prace naukowe ogłaszane na łamach innych czasopism.

Do sprawy niezrealizowanego projektu uruchomienia zajęć na USB ks. Hieronim Feicht powrócił w liście do Adolfa Chybińskiego w styczniu 1927 roku. W tym celu przedstawił kroki, jakie uważał za słuszne:

29 BJ OZS, Korespondencja A. Chybińskiego, teka: F-3/1, list bez sygn., List ks. H. Feichta do A. Chybińskiego, Wilno 6 XII 1926, rkps, k. nlb.

30 Ibidem.

31 Ibidem.

32 Zob. stronę Instytutu Muzykologii KUL: http://www.kul.pl/o-instytucie, 11122. html, dostęp: 03.03.2018. 
niech Uniw. [ersytet] wileński wniesie urzędowe podanie, poparte odpowiednimi argumentami wraz z wstawieniem się x. Arcybp. wileńskiego [ks. abp Romualda Jałbrzykowskiego] czy innych czynników. Ja mogę o tych ponowionych staraniach nic nie wiedzieć, a co do P. Profesora zdaje mi się, że również nie będzie wskazane narażać się na ewentualną odmowę.

Ksiądz Feicht przeczuwał też niepowodzenie, gdyby zgromadzenie misjonarzy dowiedziało się, że inspiracja powołania wykładów wyszła od Chybińskiego, dlatego tym bardziej prosił go, by nie stosował oficjalnych pism do władz uczelni:

Niech to będzie zrobione tak, by naprawdę u naszych czynników wywarło wrażenie, że Uniw.[ersytet] nie robi tego z inspiracji, czy na życzenie wywołane ze strony P. Profesora. Lecz ma osobiste swoje powody do tego kroku. Czy to odniesie skutek tego nie mogę zaręczyć, choć jestem skłonny przypuszczać, że raczej nie ${ }^{33}$.

Mimo że ks. Feicht domyślał się fiaska całego przedsięwzięcia, widział w oficjalnym zwróceniu się USB do władz zakonu możliwość podniesienia własnego prestiżu w zgromadzeniu, z którego władzami od momentu niespodziewanego przeniesienia go do Wilna miał nie najlepsze stosunki, a jeszcze gorsze od listopada 1926 roku, gdy aż miesiąc musiał czekać na jedno ze swoich pism w sprawie urlopu wysłanego do zgromadzenia w Krakowie: „W każdym razie takie urzędowe zwrócenie się poważnej instytucji wzmocni moją sytuację w Zgromadzeniu, a jeśli odmówią, muszę to zrobić tak, by mnie nie zadrażnić, bo żyję w »urzędowym « stosunku z władzą naszą i okazuje się, że ta droga obrana jest dobrą"34.

Jednocześnie ks. Feicht nie chciał jeszcze bardziej pogarszać stosunków z władzami zgromadzenia, które wolały jego urlop oddalić. W tym celu nawet radził się Chybińskiego, nie wiedząc, jak ma zareagować, aby w końcu wyczekiwany urlop (dla pracy naukowej) uzyskać, ale jednocześnie nie zadrażniając sytuacji: „Nawet nie wiem, jaką mądrą dać

33 BJ OZS, Korespondencja A. Chybińskiego, teka: F-3/1, list bez sygn., List ks. H. Feichta do A. Chybińskiego, Wilno 22 I 1927, rkps, k. nlb.

34 Ibidem. 
odpowiedź na to pytanie, by sobie sprawy jakiego trzymiesięcznego lub półrocznego wypoczynku nie popsuć, bo bardzo on potrzebny, zwłaszcza dla... Pękiela" ${ }^{35}$. Ks. Feicht planował zatem podczas urlopu kontynuować prace dotyczące Bartłomieja Pękiela, zapoczątkowane podczas studiów we Lwowie.

Kolejny raz do kwestii zajęć z muzykologii na USB ks. Feicht nawiązał - już jedynie przy okazji - w liście do Chybińskiego z 2 czerwca 1927 roku, pisząc: „W sprawie kroków o wykładanie na uniw.[ersytecie] wil.[eńskim] byłoby wiele do pomówienia" ${ }^{36}$. Tak brzmiały ostatnie słowa napisane przez niego na ten temat. Jednocześnie ks. Feicht zauważył początek zmian stosunku zakonu misjonarzy do jego pracy naukowej, relacjonując Chybińskiemu: „Zgromadzenie przekonało się już, że Wilno nie miejsce dla mnie" ${ }^{37}$, dlatego coraz bliższa stawała się możliwość rocznego wyjazdu zagranicznego, umożliwiającego dalszy rozwój naukowy. Władze zakonu zorientowały się bowiem, że właściwie poza osobą ks. Feichta brak w nim reprezentantów czynnie zajmujących się nauką. Było to istotne, zwłaszcza w obliczu konieczności objęcia w przyszłości rektoratu konwiktu teologicznego w Warszawie. Ks. Feicht pisał: „Nasze władze zrozumiały, skoro się spostrzegły, że wśród młodszych nie mają żadnego księdza pracującego naukowo, mimo wielu księży z doktoratami" 38 .

Dlatego też ks. Feicht nie nalegał już, by objąć prowadzenie zajęć na Wydziale Teologicznym USB, gdzie mógłby raczej nauczać śpiewu chorału gregoriańskiego niż prowadzić zajęcia stricte muzykologiczne: „Otóż jeżeli nie będę w Wilnie długo, to nie wiem czy warto by brać coś - zwłaszcza na teologii, gdzie pracę ocenią tylko z wyników praktycznych. Przez rok nie wiele nauczyłbym kleryków chorału" ${ }^{39}$. Jak już wspomniano, ks. Feicht miał doświadczenie z prowadzenia wykładów z muzyki kościelnej i ćwiczeń

35 BJ OZS, Korespondencja A. Chybińskiego, teka: F-3/1, list bez sygn., List ks. H. Feichta do A. Chybińskiego, Wilno 27 I 1927, rkps, k. nlb.

36 BJ OZS, Korespondencja A. Chybińskiego, teka: F-3/1, list bez sygn., List ks. H. Feichta do A. Chybińskiego, Wilno 02 VI 1927, rkps, k. nlb.

37 Ibidem.

38 Ibidem.

39 Ibidem. 
z chorału gregoriańskiego na UJK ${ }^{40}$. Rozważał przy tym za i przeciw podjęcia się prowadzenia zajęć na USB: „Wobec sfer naukowych byłoby rzeczą ważną, że uczyłem już na uniw.[ersytecie] lwowsk.[im] i wileńsk.[im] ale w sferach duchowieństwa mogliby i tak powiedzieć: i tu nic nie zrobił i tam nic nie zrobił no i wniosek jasny" ${ }^{41}$. Ważniejsza dla ks. Feichta od samego prowadzenia zajęć była jego indywidualna praca naukowa, dlatego chciał w roku następnym wypocząć po trudach związanymi z obowiązkami obejmowanymi w seminarium w Wilnie „i nieco jeszcze się oczytać, a może i wykończyć Pękiela”. O wyjeździe zagranicznym nie myślał jednak jako o okazji do wypoczynku, tylko do pracy naukowej ${ }^{42}$.

Należy dodać, że ks. Feicht, chociaż nie prowadził zajęć na USB, działał w Wilnie także jako muzykolog. Nie stracił bowiem swego dotychczasowego zamiłowania do poznawania zasobów archiwów i bibliotek. Myślał o tym już w pierwszym miesiącu po przyjeździe latem 1926 roku, jednak w związku z nowymi obowiązkami w seminarium musiał plany te wciąż odkładać ${ }^{43}$. Dopiero po powrocie z rocznych studiów odbytych we Fryburgu (październik 1927 - czerwiec 1928), latem 1928 roku z Krakowa udał się w tym celu do Wilna. Po prawie dwutygodniowych poszukiwaniach ks. Feicht, swoim zwyczajem, zdał Chybińskiemu szczegółową listowną relację ${ }^{44}$, po raz pierwszy poruszając zagadnienie zabytkowych muzykaliów przechowywanych w Wilnie ${ }^{45}$.

List ten stanowi ważny dokument dotyczący muzykaliów znajdujących się w Bibliotece Uniwersyteckiej i Bibliotece Wróblewskich. Ks. Feicht natrafił tam na muzykalia od XVI do XIX wieku włącznie, które dość

40 DALO, f. 26, op. 5, cp. 2015 [Pismo dziekana ks. Piotra Stacha do A. Chybińskiego], Lwów 12 V 1925, mps, k. 43; Kronika Uniwersytetu Jana Kazimierza we Lwowie za rok szkolny 1924/25, Lwów 1924, s. 101.

41 BJ OZS, Korespondencja A. Chybińskiego, teka: F-3/1, list bez sygn., List ks. H. Feichta do A. Chybińskiego, Wilno 02 VI 1927, rkps, k. nlb.

42 Ibidem.

43 Z okresu wileńskiego (sierpień 1926-lipiec 1927) nie posiadamy żadnego listu z opisem jakiejkolwiek kwerendy w archiwach i bibliotekach.

44 BJ OZS, Korespondencja A. Chybińskiego, teka: F-3/1, list bez sygn., List ks. H. Feichta do A. Chybińskiego, Wilno, 13 VIII 1928, rkps, k. nlb.

45 Pełna treść listu wraz z jego szczegółowym omówieniem zob. M. Piekarski, Przerwany kontrapunkt, s. 290-291. 
szczegółowo opisał. Dzielił się z Chybińskim swoją sugestią, aby muzykalia Biblioteki Uniwersyteckiej zinwentaryzował Tadeusz Szeligowski (będzie o nim mowa). Choć nie miał on doktoratu z muzykologii, ks. Feicht uznał, że podołałby zadaniu, co pisząc o zbiorach motywował: „gdyż nie przedstawiają one nadzwyczajnych trudności” ${ }^{46}$. Nie wiadomo jednak, czy Szeligowski opis taki stworzył, choć dokonywał w tym czasie w Wilnie kwerend, przygotowując pracę doktorską poświęconą dziejom polskiej opery ${ }^{47}$.

W 1932 roku zbiory muzyczne Biblioteki Uniwersyteckiej opisał za to zatrudniony tam Michał Brensztejn ${ }^{48}$. Nie mając jednak wykształcenia muzykologicznego, zrobił to pobieżnie, mimo że miał sprzyjające warunki jako pracownik miejscowy ${ }^{49}$. Poszukiwania w Bibliotece Wróblewskich okazały się dla ks. Feichta już mniej satysfakcjonujące. Nie dostrzegał też potrzeby wypisywania zgromadzonych tam zbiorów muzycznych, wiedząc, że zostały już zinwentaryzowane przez Helenę Drège, która w okresie pobytu ks. Feichta w Wilnie pracowała w Bibliotece Uniwersytetu Wileńskiego i zajmowała się reorganizacją Biblioteki Wróblewskich ${ }^{50}$.

Komentarze ks. Feichta, które zawarł we wspomnianym liście do Chybińskiego, zasługują na uwagę, świadcząc o tym, że niejednokrotnie wykraczał poza swoje zainteresowania badawcze, chcąc zapoznać się z całokształtem kultury muzycznej ziem polskich. Cenne są również dlatego, gdyż do dziś nie wiadomo, czy jakikolwiek inny muzykolog w okresie międzywojennym dokonał bardziej szczegółowej kwerendy zbiorów wileńskich. Sugerują też znajomość ks. Feichta z Tadeuszem Szeligowskim.

46 BJ OZS, Korespondencja A. Chybińskiego, teka: F-3/1, list bez sygn., List ks. H. Feichta do A. Chybińskiego, Wilno, 13 VIII 1928, rkps, k. nlb.

47 Opis taki nie zachował się w spuściźnie po kompozytorze. Informację zawdzięczam Bogumile Szeligowskiej-Wojteckiej. Zob. T. Szantruczek, Komponować i umrzeć. Rzecz o Tadeuszu Szeligowskim, Poznań 1997, s. 47.

48 Michał Brensztejn (1874 Telsze - 1938 Wilno), w latach 1919-1938 bibliotekarz Biblioteki Uniwersyteckiej USB, asystent w Katedrze Antropologii USB.

49 M. Brensztejn, Zbiór nut Uniwersyteckiej Biblioteki Publicznej, [w:] Biblioteki wileńskie, red. A. Łysakowski, Wilno 1932, s. 91-92.

50 Helena Drège (ur. w 1888 r. w Kole - zm. w 1956 r. w Świdrze k. Warszawy), od 1925 r. jako sekretarz Komitetu Pomocy Naukowej im. E.E. Wróblewskich zajmowała się reorganizacją biblioteki (założonej w 1912 r., upaństwowionej w 1926 r.), od 1929 r. pełniła funkcję wicedyrektora i kierownika działu Zbiorów Specjalnych. 


\section{„Alma Mater Vilnensis” a muzykologia}

W okresie kiedy ks. Feicht bezskutecznie ubiegał się o współpracę z USB, w wydawanym przez uczelnię roczniku „Alma Mater Vilnensis” ukazał się artykuł Tadeusza Szeligowskiego (ur. w 1896 roku we Lwowie, zm. w 1963 roku w Poznaniu) ${ }^{51}$, podejmujący kwestię potrzeby wprowadzenia zajęć z muzykologii ${ }^{52}$. Autor pochodził ze Lwowa, gdzie odebrał edukację muzyczną, którą uzupełniał w Krakowie, zdobywając równocześnie wykształcenie uniwersyteckie na Wydziale Prawa UJ. W Krakowie uczęszczał także na zajęcia Zdzisława Jachimeckiego (1921-1923). W chwili publikacji artykułu Szeligowski od czterech lat mieszkał już w Wilnie, gdzie pracował w Prokuratorii Generalnej, należąc także do Wileńskiego Towarzystwa Filharmonicznego oraz Związku Literatów jako animator sekcji muzycznej ${ }^{53}$. Mimo że nie ukończył studiów muzykologicznych, miał jednak dobre rozeznanie w zakresie tej dyscypliny, widząc potrzebę wprowadzenia jej w mury wileńskiej uczelni. Wspomniany artykuł powstał na zamówienie redakcji. Szeligowski stwierdził, że dotąd na sprawy muzyczne zwracano na USB niewiele uwagi, w tym na problem muzykalności studentów. Dwie zasadnicze podniesione przez Szeligowskiego kwestie to: wykłady z muzykologii oraz reaktywacja chóru akademickiego USB. Zwrócił uwagę, że w wileńskiej Alma Mater studenci nie mają żadnej możliwości zaznajomienia się z zagadnieniami muzycznymi podczas studiów (w przeciwieństwie np. do literatury i malarstwa).

51 Szeligowski po ukończeniu Konserwatorium GTM we Lwowie kształcił się na Wydziale Prawa Uniwersytetu Wiedeńskiego, po czym (po przerwie) kontynuował edukację na UJK, ostatecznie kończąc studia na UJ. W Krakowie równocześnie pogłębiał wiedzę muzyczną u B. Wallek-Walewskiego. W 1923 r. przeniósł się do Wilna. A. Mrygoń, Szeligowski Tadeusz, [w:] Encyklopedia muzyczna PWM, red. E. Dziębowska, t. 10, Kraków 2007, s. 239-240.

52 T. Szeligowski, O potrzebie muzycznego wychowania mtodzieży akademickiej, „Alma Mater Vilnensis" 1927, trymestr II.

53 A. Mrygoń, op. cit., s. 239-240; T. Szantruczek, Komponować i umrzeć, s. 41. 


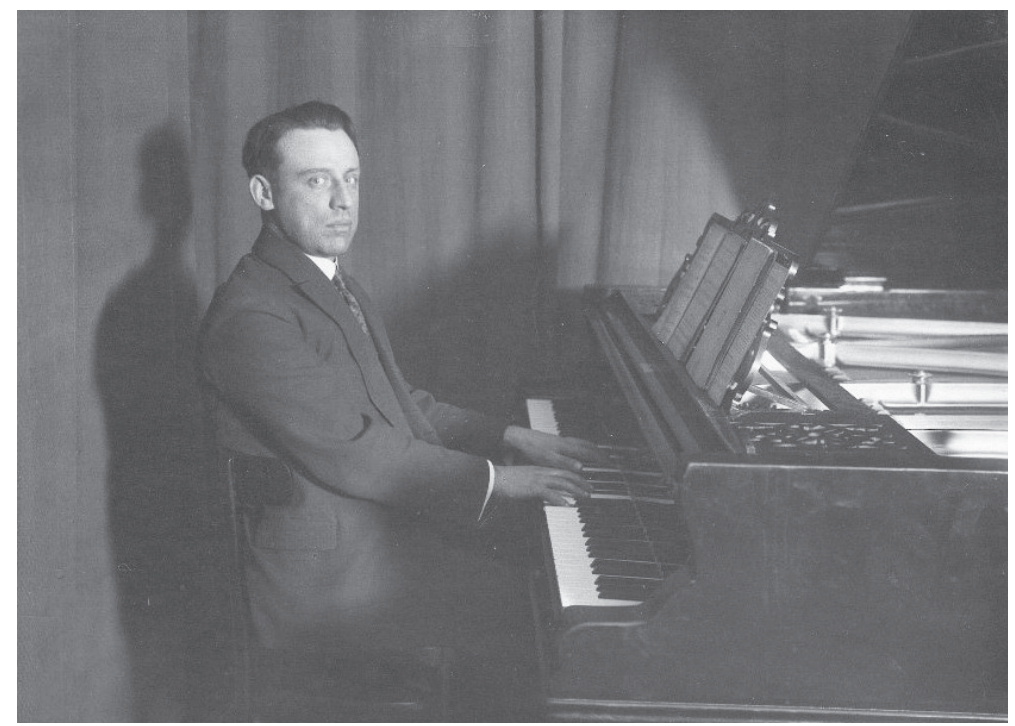

Ryc. 3. Tadeusz Szeligowski. Fotografia ze zbiorów Bogumiły Szeligowskiej-Wojteckiej

Porównywał taki stan rzeczy z innymi uniwersytetami, stwierdzając, że „sytuacja w szeregach młodzieży akademickiej Lwowa i Krakowa jest pod tym względem niepomiernie pomyślniejsza" ${ }^{4}$. Wskazał jednocześnie na obecność studiów muzykologicznych w wymienionych uczelniach, spełniających odpowiednie oczekiwania: „Istniejące w tych miastach katedry muzykologii pozwalają ciekawszemu na bliższe obcowanie z muzyką i przyczyniają się do teoretycznego wykształcenia, nieodzownego dla należytego rozumienia muzyki”55. Warto dodać, że podobnie w 1912 roku potrzebę wprowadzenia muzykologii w mury Uniwersytetu Lwowskiego uzasadniał Adolf Chybiński w swoim wykładzie inauguracyjnym „Uniwersytet a muzyka”, m.in. stwierdzając: „Są to dwie różne rzeczy, dzieła sztuki doznawać estetycznie, a dzieło to rozumieć" 56 . Wykład Chybińskiego został opubli-

54 T. Szeligowski, op. cit., s. 53.

55 Ibidem.

56 A. Chybiński, Uniwersytet a muzyka, „Przegląd Muzyczny” 1913, nr 2, 15 I, s. 1-5; zob. M. Piekarski, „Uniwersytet a muzyka”. Droga do powotania we Lwowie Zaktadu Muzykologii, „Rozprawy z Dziejów Oświaty” 2014, t. LI. 
kowany w 1913 roku, gdy Szeligowski mieszkał we Lwowie, gdzie pobierał edukację muzyczną w Konserwatorium Galicyjskiego Towarzystwa Muzycznego.

Szeligowski poddawał pomysł utworzenia na USB katedry muzykologii lub wprowadzenia zleconych wykładów. Wskazywał jednocześnie, że zmagający się z wieloma trudnościami chór akademicki USB (służący poprawie muzykalności środowiska uniwersyteckiego) mógłby znaleźć „odpowiedniego orędownika w wykładającym muzykologię" 57 . Szeligowski pojawienie się muzykologa na USB wiązał zatem z ogólną poprawą statusu obecności muzyki (zarówno w postaci teoretycznej, jak i praktycznej) w murach wileńskiej Alma Mater. Znana była mu zatem kwestia kurateli Chybińskiego nad Chórem akademickim UJK. Chór akademicki USB został reaktywowany już w 1927 roku dzięki objęciu kierownictwa przez Szeligowskiego ${ }^{58}$.

Jak wspomniano, czas opublikowania artykułu Szeligowskiego zbiegł się akurat z pobytem ks. Feichta w Wilnie, choć jego autor bezpośrednio się do tego nie odnosił. Co jednak zastanawia, ks. Feicht nazwisko Szeligowskiego w listach do Chybińskiego wymienił tylko raz (w związku ze wspomnianą inwentaryzacją muzykaliów). Możliwe zatem, że nie nawiązali bliższych relacji, w czym przeszkodą mógł być latami trwający konflikt Chybińskiego z Jachimeckim (niejednokrotnie przenoszony na uczniów) ${ }^{59}$. Co istotne, sam Szeligowski również planował na USB prowadzić zajęcia z muzykologii, do czego potrzebny był mu jednak doktorat z tej dyscypliny (być może jako uczeń Jachimeckiego chciał tym bardziej zdystansować ks. Feichta na gruncie wileńskim, co też motywowało go do działania). Pisał o tym w styczniu 1927 roku do Stanisławy Harasowskiej (jego późniejszej żony): „od 1 lipca rzucam Prokuratorię by wykończyć doktorat, po zrobieniu którego mam ofertę na zastępcę profesora, a po habilitacji na nadzwy-

T. Szeligowski, op. cit., s. 54. Chór akademicki istniał od roku akademickiego 1920/1921. Zob. M. Ankudowicz-Bieńkowska, Polskie życie muzyczne w Wilnie lat II Rzeczypospolitej, Olsztyn 1997, s. 85; P. Tomaszewski, Chór studentów USB w Wilnie w dwudziestoleciu międzywojennym, „Muzyka” 2016, nr 2.

58 M. Ankudowicz-Bieńkowska, op. cit., s. 85, 122.

59 M. Piekarski, Przerwany kontrapunkt, s. 182, 184. 
czajnego" ${ }^{0}$. W ten sposób Szeligowski planował, podobnie jak zrobił to Kamieński na Uniwersytecie Poznańskim, objąć stanowisko zastępcy profesora, umożliwiające prowadzenie wykładów z muzykologii. Do obrony doktoratu z muzykologii konieczne było absolutorium na Wydziale Humanistycznym, które Szeligowski uzyskał w 1928 roku, po dwóch latach zdawania kolejnych egzaminów ${ }^{61}$. Pracę doktorską Szeligowski przygotowywał w latach 1923-1928 pod kierunkiem Zdzisława Jachimeckiego. Nie doszło jednak do jej obrony ${ }^{62}$.

Zaniechanie niebawem kariery akademickiej przez Szeligowskiego wiązało się z coraz większym zaangażowaniem w zakresie kompozycji, którą na szerszą skalę zaczął się zajmować w 1926 roku (muzykę do sztuk teatralnych komponował już od 1923 roku ${ }^{63}$. Wyjątkowo istotna stała się bardzo pozytywna opinia Karola Szymanowskiego, którego Szeligowski poprosił o ocenę swoich prac kompozytorskich. Słowa mistrza miały, jak się okazało, decydujące znaczenie dla dalszych losów Szeligowskiego, choć jeszcze przez dwa lata dążył on do uzyskania doktoratu z muzykologii. Opinią tą (wyrażoną w liście z grudnia 1926 roku) Szeligowski podzielił się ze Stanisławem Węsławskim, również prawnikiem i jednocześnie kompozytorem (obaj należeli do niejednej wspólnej organizacji), wysoko ceniącym zdanie Szymanowskiego - jak przytaczał Szeligowski Harasowskiej - „Węsławski wyraził się, że taki list bardziej by go ucieszył aniżeli... Polonia Restituta. Ja twierdzę w zupełności to samo" ${ }^{64}$. Odtąd Szeligowskiego coraz bardziej pochłaniała kompozycja, a zainteresowa-

60 T. Szantruczek, Postać i losy kompozytora na podstawie listów z lat 1922-1932, [w:] Tadeusz Szeligowski. Studia i wspomnienia, red. H. Martenka, Bydgoszcz 1985, s. 58.

61 A. Sieczka, Szeligowski Tadeusz, [w:] PSB, t. 48, Warszawa-Kraków 2012-2013, s. 10 .

62 Praca - jak się wydaje - została ukończona. Autor w 1929 r. miał ją zabrać ze sobą do Paryża, gdzie zaginęła. T. Szantruczek, Errata do biografii, [w:] Tadeusz Szeligowski: wokót twórcy i jego dzieta, red. T. Brodniewicz, J. Kempiński, J. Tatarska, Poznań 1998, s. 17.

63 Począwszy od muzyki do Irydiona Krasińskiego wystawionego w Teatrze na Pohulance; T. Szantruczek, Komponować i umrzeć, s. 191.

64 T. Szantruczek, Postać i losy kompozytora, s. 65. 
nie badaniem muzyki słabło ${ }^{65}$. W konsekwencji takiego wyboru Szeligowski w latach 1929-1931 jako stypendysta MWRiOP studiował w Paryżu kompozycję u Nadii Boulanger i instrumentację u Paula Duckasa. Plany związane z doktoratem z muzykologii ostatecznie zarzucił. $Z$ tych powodów projekt powołania na USB zajęć z muzykologii w latach dwudziestych wciąż pozostawał jedynie w sferze planów.

Pomysł wprowadzenia zajęć o tematyce muzycznej w Wilnie jednak powrócił i został zrealizowany na Wydziale Humanistycznym USB w roku akademickim 1933/1934. Ostatecznie ich prowadzenie objął właśnie Tadeusz Szeligowski, który przez sześć lat (1933/1934-1938/1939) zatrudniony był na Wydziale Humanistycznym USB jako lektor muzyki ${ }^{66}$ (jedynie w roku akademickim 1934/1935 widniało: „lektor muzykologii”) ${ }^{67}$. Ponieważ nie miał ani habilitacji, ani doktoratu z muzykologii, pozostawał mu wyłącznie lektorat. Tego rodzaju praca nie angażowała nadmiernie czasowo, pozwalając na zajęcie się kompozycją. Szeligowski lektorat na USB łączył też z obowiązkami wykładowcy w Konserwatorium Muzycznym w Wilnie, w którym pracował od 1932 roku, w latach 1935-1939 również jako jego wicedyrektor ${ }^{68}$. Charakterystyczne było więc to, że na USB lektorat muzykologii (nazywany też „lektoratem muzyki”) prowadził aktywnie działający kompozytor. Do jego twórczości należy m.in. wykorzystująca lokalny

65 W 1929 r. Szeligowski stwierdził: „Zaczynam niestety nie lubić »uczoności« i szperania w księgach [...] widocznie moje tendencje artystyczne pobudzają mnie do tego", ibidem, s. 57-58.

66 Uniwersytet Stefana Batorego $w$ Wilnie. Sktad uniwersytetu $w$ roku akademickim 1933/1934, Wilno [1933], s. 10; Uniwersytet Stefana Batorego w Wilnie. Sktad uniwersytetu w roku akademickim 1935/1936, Wilno [1935], s. 9; Uniwersytet Stefana Batorego w Wilnie. Sktad uniwersytetu w roku akademickim 1936/1937, Wilno [1936], s. 9; Uniwersytet Stefana Batorego w Wilnie. Sktad uniwersytetu w roku akademickim 1937/1938, Wilno [1937], s. 9; Uniwersytet Stefana Batorego w Wilnie. Sktad uniwersytetu w roku akademickim 1938/1939, Wilno [1939], s. 129.

67 Uniwersytet Stefana Batorego w Wilnie. Sktad uniwersytetu w roku akademickim 1934/1935, Wilno [1934], s. 9.

68 W Konserwatorium Muzycznym w Wilnie prowadził: kontrapunkt, formy muzyczne, instrumentację i kompozycję; Dziesięciolecie Konserwatorium Muzycznego w Wilnie 1923-1933, Wilno 1933, s. 4. Od 1935 r. nosiło nazwę Konserwatorium Muzycznego im. M. Karłowicza. 
koloryt suita na orkiestrę „Kaziuki” z 1928 roku. Utwory Szeligowskiego (np. „Pieśni zielone”) prezentowano m.in. w ramach koncertów powstałego w 1930 roku wileńskiego oddziału Towarzystwa Muzyki Współczesnej, do którego należał kompozytor, prezesem zaś był wspomniany już wcześniej Stanisław Węsławski ${ }^{69}$. Obydwu (byli zresztą rówieśnikami) łączyły bliskie relacje towarzyskie, ponadto obaj pisali też muzykę dla Rozgłośni Polskiego Radia w Wilnie, w której stanowisko referenta muzycznego zajmował Węsławski ${ }^{70}$.

Lektorat muzykologii na USB obejmował w kolejnych latach: formy muzyczne i ćwiczenia z zakresu badań nad muzyką ludową $(1936 / 1937)^{71}$, twórczość Richarda Wagnera i ćwiczenia z zakresu badań nad pieśnią ludową (1937/1938) ${ }^{72}$, twórczość Fryderyka Chopina, ćwiczenia z zakresu harmonii, formy muzyki jednogłosowej $(1938 / 1939)^{73}$. Zajęcia odbywały się z ilustracją muzyczną ${ }^{74}$. Tematyka lektoratu wskazuje na powiązania z nowymi tendencjami obecnymi w planach dydaktycznych katedr muzykologii Uniwersytetu Poznańskiego (od roku akademickiego 1929/1930)

69 S. Węsławski, Wilno. Koncerty. Dziatalność Polskiego Tow. Muzyki Wspótczesnej, „Muzyka” 1931, nr 1, s. 38; P. Dąbrowski, Wileńska dziatalność spoteczno-kulturalna i oświatowa Stanistawa Westawskiego (1896-1942) - przyczynek do biografii, „Res Historica” 2015, nr 39, s. 198; D. Berezowska, Dziatalność zespotów i zrzeszeń muzycznych $w$ Wilnie (1930-1939), „Nasz Czas” 2002, nr 36.

70 Obydwaj należeli też do zarządu Rady Wileńskich Zrzeszeń Artystycznych. M. Ankudowicz-Bieńkowska, op. cit., s. 172, 197.

71 Z lat wcześniejszych nie posiadamy szczegółowego spisu tematyki zajęć. Uniwersytet Stefana Batorego. Spis wyktadów w roku akademickim 1936/1937, Wilno [1936], s. 13. W roku akademickim 1936/1937 tematykę zajęć do spisu dopisano ręcznie, w późniejszych latach podawano już w druku.

72 Uniwersytet Stefana Batorego. Spis wyktadów w roku akademickim 1937/1938, Wilno [1937], s. 14.

73 Uniwersytet Stefana Batorego. Spis wyktadów w roku akademickim 1938/1939, Wilno [1938], s. 17.

74 Prowadzenie zajęć z ilustracją z użyciem fortepianu w dziejach polskiej muzykologii zapoczątkował Chybiński we Lwowie już w 1912 r.; M. Piekarski, Przerwany kontrapunkt, s. 210. W Wilnie w zajęciach poświęconych Wagnerowi wykorzystywano gramofon. Zob. Uniwersytet Stefana Batorego. Spis wyktadów w roku akademickim 1937/1938, Wilno 1937, s. 14 . 
i Uniwersytetu Jagiellońskiego (od roku akademickiego 1935/1936), gdzie wprowadzono zajęcia poświęcone etnografii muzycznej ${ }^{75}$. Widniały one też w spisach wykładów UW (od roku akademickiego 1937/1938)76. Do końca 1939 roku nie figurowały jednak w planach zajęć ukierunkowanej wyłącznie na muzykologię historyczną Katedry Muzykologii UJK. Co zasługuje na uwagę, w Wilnie zajęcia z etnografii muzycznej pojawiły się co najmniej o rok wcześniej niż w Warszawie (przed 1936 rokiem na USB nie podawano tematyki lektoratu). Powyższe kwestie, jak również to, że na USB lektorat z muzykologii odbywał się w siedzibie Zakładu Etnologii (ulica Zamkowa 11), wskazują na to, że w Wilnie lektorat ten był uzupełnieniem zajęć prowadzonych w ramach etnologii. Spełniało to postulat, jaki przedstawiła w 1933 roku Cezaria Baudouin de Courtenay, kierownik Seminarium Etnologii i Etnografii USB, pisząc: „brak odpowiedniego fonografu i wykształcenia muzykologicznego uniemożliwia po prostu osiągnięcie właściwych pracy przez zbieraczy" ${ }^{\prime \prime}$. Ważnym impulsem inspirującym etnologię wileńską do rozpoczęcia zbierania melodii ludowych mogło być też powołanie w 1929 roku przy Katedrze Muzykologii Uniwersytetu Poznańskiego pierwszego w Polsce archiwum fonograficznego ${ }^{78}$. Prowadzone na USB zajęcia z muzykologii nie mogły jednak utorować drogi do powstania samodzielnej katedry, ponieważ Szeligowski nie miał ani formalnego wykształcenia muzykologicznego, ani habilitacji. Sytuacja taka utrzymywała się do 1939 roku.

75 Zob. M. Piekarski, Przerwany kontrapunkt, s. 215, 269.

76 Uniwersytet Józefa Pitsudskiego w Warszawie. Sktad uniwersytetu i spis wyktadów na rok akademicki 1937-1938, Warszawa 1937, s. 65-66.

77 C. Baudouin de Courtenay-Ehrenkreutzowa, Zaktad Etnologii Uniwersytetu Stefana Batorego w Wilnie i jego zadania, Wilno 1933, s. 90.

78 M. Piekarski, Przerwany kontrapunkt, s. 162. 


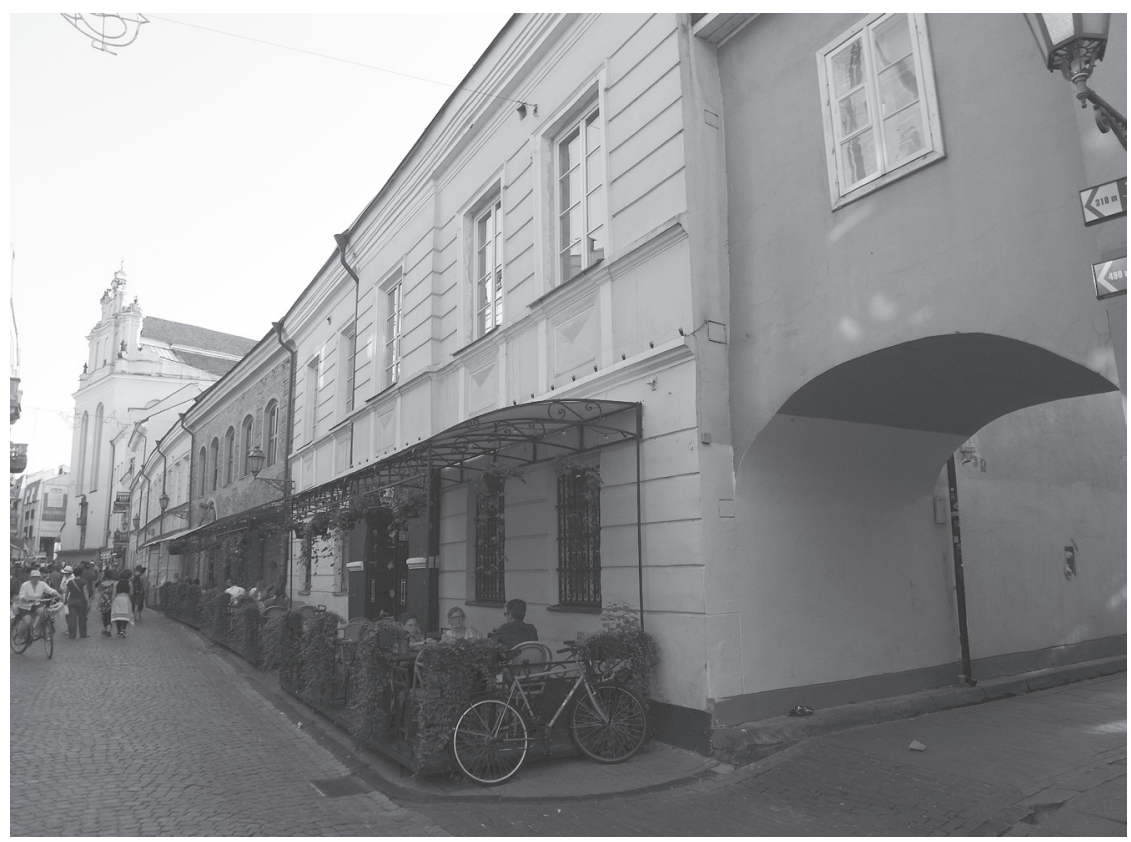

Ryc. 4. Wilno, ul. Zamkowa 11. Fot. autor

Muzykologia na ziemiach polskich najszybciej pojawiła się na uniwersytetach galicyjskich, co jest zrozumiałe ze względu na wpływ Uniwersytetu Wiedeńskiego z jednej strony, a z drugiej na działalność w dobie autonomii polskich uczelni, chcących w ten sposób zapewnić kulturze narodowej wszystkie możliwe aspekty jej rozwoju. Choć w Poznaniu do 1919 roku nie było uniwersytetu, wykłady z muzykologii pojawiły się tam już w pierwszym roku istnienia uczelni, na co wpływ mógł wywierać stosunkowo niedaleki Berlin. Z kolei Warszawa i Wilno do 1915 roku pozostawały w granicach Rosji, gdzie nie było w ogóle uniwersyteckiej muzykologii. Tradycje te (a raczej ich brak) mogły też zaważyć na tym, że na Uniwersytecie Stefana Batorego oraz Uniwersytecie Warszawskim przez cały okres międzywojenny nie powołano katedr muzykologii. Na obydwu uczelniach próbowano do tego doprowadzić w podobny sposób, poczynając od wprowadzenia zajęć o tej tematyce, jak w Krakowie i Lwowie ponad 20 lat wcześniej. 
Krótki epizod ks. Hieronima Feichta w Wilnie wskazuje na nieznany dotąd aspekt z dziejów USB, a także na przepływ idei związanych z nauką uprawianą w dawnej Galicji na uczelnię wileńską. Wzmacnia też pogląd stwierdzający, że USB w niemałym stopniu swój rozwój zawdzięczał osobom wywodzącym się ze środowiska lwowskiego, z którego pochodził zarówno ks. Hieronim Feicht, jak i Tadeusz Szeligowski. To, że USB w tym samym czasie ubiegał się o objęcie zajęć z muzykologii przez jednego z nich, świadczy o tym, że władzom uczelni zależało na jak najszybszym wprowadzeniu do spisu zajęć nowej dyscypliny. Podobnie zresztą czynił Uniwersytet Lwowski przed 1911 rokiem, nawiązując kontakt zarówno z Adolfem Chybińskim, jak i ze Zdzisławem Jachimeckim. Przypadek USB ukazuje też, jak działalność obydwu profesorów kontynuowana była w Wilnie za sprawą ich uczniów.

Należy zwrócić uwagę, że Wilno o dwa lata wyprzedziło Warszawę w zatrudnieniu wykładowcy zajęć o tematyce muzycznej - Tadeusz Szeligowski rozpoczął swoją działalność na USB w 1933 roku, a Julian Pulikowski na UW dopiero w 1935 roku. Świadczy to o prężności władz wileńskiej uczelni, która mogła nawet w pewnych działaniach wyprzedzać większą od siebie uczelnię stołeczną. Z kolei poczynania USB mogły wpływać ambicjonalnie na władze UW, przyczyniając się do przyspieszenia działań w tym kierunku. Warto dodać, że podobnie jak Szeligowski w Wilnie, Pulikowski w Warszawie oprócz prowadzenia zajęć na UW zatrudniony był też w miejscowym konserwatorium muzycznym. Z kolei zarówno w Wilnie, jak i w Poznaniu zajęcia z muzykologii prowadzone były przez aktywnie działających kompozytorów; co należy jednak zaznaczyć, ranga na tym polu Szeligowskiego jest o wiele wyższa niż Kamieńskiego.

Ponadto w Wilnie zwraca uwagę powiązanie zajęć z muzykologii z Seminarium Etnologii i Etnografii, dzięki czemu wileńscy etnolodzy mogli rozpocząć badania nad muzyką ludową. Niezależnie od tego lektorat prowadzony przez Szeligowskiego wykraczał znacznie poza pole badawcze dotyczące etnologii, poruszając m.in. zagadnienia twórczości Chopina i Wagnera. Mogło to świadczyć o trwających wciąż planach wprowadzenia na szerszą skalę muzykologii w mury wileńskiej uczelni. 